\title{
Experimental-Numerical Study of Tensile Strength of the High-Strength Steel S690QL at Elevated Temperatures
}

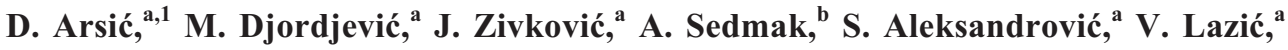 \\ D. Rakića \\ ${ }^{a}$ Faculty of Engineering, University of Kragujevac, Kragujevac, Serbia \\ ${ }^{b}$ Faculty of Mechanical Engineering, University of Belgrade, Belgrade, Serbia \\ ${ }^{1}$ dusan.arsic@fink.rs
}

УДК 539.4

\section{Экспериментально-численное исследование прочности при растяжении высокопрочной стали S690QL в условиях повышенных температур}

\author{
Д. Арсич ${ }^{a}$, М. Джорджевич ${ }^{\mathrm{a}}$, Е. Живкович ${ }^{\mathrm{a}}$, А. Седмак ${ }^{6}$, С. Александрович ${ }^{\mathrm{a}}$, \\ В. Лазич ${ }^{a}$, Д. Ракич \\ a Крагуевацкий университет, Крагуевац, Сербия \\ ${ }^{\sigma}$ Белградский университет, Белград, Сербия
}

Представлены результаты расчетно-экспериментального анализа влияния температуры на механические свойства высокопрочной конструкционной стали S690QL. Определена максимальная температура при статических испытаниях на растяжение, при которой данная сталь сохраняет высокие механические характеристики. Статические испытания на растяжение проводились при пяти различных температурах в диапазоне $20 \ldots 550^{\circ}$ С. Полученные экспериментальные данные сравнивались с результатами конечноэлементных расчетов путем построения соответствующих кривых упрочнения стали.

Ключевые слова: сталь S690QL, температура, механические свойства, конечноэлементный численный анализ, эквивалентное напряжение, эффективная деформация.

Introduction. With constant advancements in the field of construction engineering, there is a growing need for high strength construction steels such as the steel grade S690QL, which is analyzed in this paper. These steels should have good mechanical properties which would make the construction reliable and light. The steel grade S690QL is used for producing high responsible constructions such as cranes, dynamic loaded parts for millitary vehicles and battle assemblies, etc [1]. When complex constructions are made, especially the ones made of steels of wide cross sections, the steel is often heated (preheated, additionally heated and tempered), and the process engineers and designers often find themselves in a dilemma concerning the maximum temperatures allowed for this process. In the literature, wide ranges of these temperatures can be found, depending on the thickness. The aim of this paper is to determine experimentaly and numericaly the maximum working temperatures at which S690QL steel keep thier high strength values.

In order to determine dependance of mechanical properties of the S690QL steel on the temperature, numerous investigations has been carried out [2-7]. Most of the investigations dealt with properties of base metal S690QL, but some papers show results of investigation of welded joints made of mentioned steel [2]. The aim of investigations was to determine

(C) D. ARSIĆ, M. DJORDJEVIĆ, J. ZIVKOVIĆ, A. SEDMAK, S. ALEKSANDROVIĆ, V. LAZIĆ, D. RAKIĆ, 2016 
the temperature at which strength of welded joints executed by GMA welding method starts to decrease. Unlike that, paper [3] analyses the behavior of base metal - S690 steel at elevated temperatures in temperature range from 20 to $700^{\circ} \mathrm{C}$. Results revealed that the drop of yield stress, tensile strength and modulus of elasticity occurs at temperatures higher than $400^{\circ} \mathrm{C}$. The steel grade S690Q was also subjected to analysis in paper [4]. The results have shown that good mechanical properties can be guaranteed up to the temperature of $400-450^{\circ} \mathrm{C}$. Young et al. [5] used temperature range from $25-800^{\circ} \mathrm{C}$ for four different high strength steels. A significant decrease in properties was also noticed at aproximately $400^{\circ} \mathrm{C}$.

Some authors also investigated the influence of elevated temperatures - fire on mechanical properties, i.e., post-fire mechanical properties [6]. Two high strength steel grades - S460 and S690 were tested. Experiment assumed uniaxial tensile testing at 12 different temperatures ranging $20-1000^{\circ} \mathrm{C}$. The obtained results showed that the yield stress and tensile strength remain unchanged up to $600^{\circ} \mathrm{C}$ but with further temperature increase a a significant decrease in yield stress is noticed, esspecially for specimens made of S690 steel. According to similar procedure, paper [7] studied the influence of elevated temperatures on mechanical properties of different construction steel grades such as S350, S355, S420, and S460 as well as austenitic steel grade X5CrNi18-10. The austenitic steel was taken as control material although it does not belong to high strength construction steels. Temperature range for experimental testing was $20-900^{\circ} \mathrm{C}$. The decreasing of mechanical properties is noticed at different temeratures $-600^{\circ} \mathrm{C}$ for construction steels, and at $670^{\circ} \mathrm{C}$ for austenitic steel. According to similar procedures in certain papers, the behavior of materials at elevated temperatures under conditions of thermal stresses [8] and fatigue loading [9] was examined.

Since some of the leading manufactors of the steel grade S690QL guarantee its mechanical properties to $580^{\circ} \mathrm{C}[10]$, it is interesting to examine the range of temperatures when decreasing of mechanical properties occurs. Our research presented in this paper assumed testing of cylindrical specimens in temperature range from 20 to $550^{\circ} \mathrm{C}$. Also, beside experimental testing, the strengthening curves were determined and the numerical analysis at all chosen temperatures was performed in order to confirm or to determine corelation rate of results obtained by experiment. The aim of numerical analysis was to predict strength of material and to shorten the time needed for experimental material testing. The numerical study shown to be very reliable for some similar testings such as welded joints [11], bucket wheel boom hoist system [12], some composite materials [13] or even transmission gears [14] and beams [15]. Also, some interesting findings on this steel can be found in research of properties of HSS S690 at low temperatures [16].

1. Experimental Testing. Specimens for the tensile testing were cylindrical and were prepared according to appropriate standards [17]. Detail scheme of specimens is shown in [1]. Experimental determination of mechanical properties at elevated temperatures was performed on a universal testing machine Zwick Roell Z100 equipped with a special chamber with furnaces for heating specimens, as shown in [2]. For each testing temperature, two test specimens were prepared. The tests were conducted at 20, 250,350,450, 500, and at $550^{\circ} \mathrm{C}$. The results are shown in Table 1, and in more details in [2]. Experimental determination of mechanical properties at elevated temperatures was performed on a universal testing machine Zwick Roell Z100 equipped with a special chamber with furnaces for heating specimens [2]. A homogenous temperature field was formed within the chamber using the controller. Three thermocouples were used to maintain the temperature and a homogenous temperature filed. Mechanical properties were determined according to the appropriate standard [18].

For each testing temperature, two test specimens were prepared. The tests were conducted at $20,250,350,450,500$, and $550^{\circ} \mathrm{C}$. The obtained results are shown in Table 1 and Fig. 1, and in [2]. 
D. Arsić, M. Djordjević, J. Zivković, et al.

\begin{tabular}{|c|c|c|}
\hline \multicolumn{3}{|c|}{ 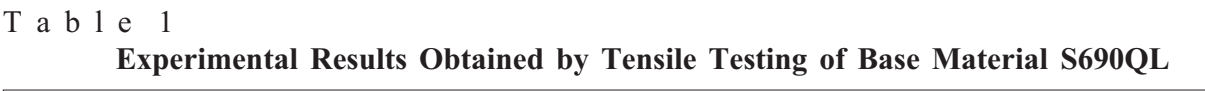 } \\
\hline Testing temperature, ${ }^{\circ} \mathrm{C}$ & $R_{p 0.2}, \mathrm{MPa}$ & $R_{m}, \mathrm{MPa}$ \\
\hline 20 & $736.65 / 736.74$ & $793.02 / 794.26$ \\
\hline 250 & $691.28 / 702.20$ & $742.76 / 754.72$ \\
\hline 350 & $665.30 / 678.94$ & $727.40 / 748.42$ \\
\hline 450 & $634.23 / 650.22$ & $718.88 / 749.42$ \\
\hline 500 & $612.48 / 617.12 / 650.22$ & $658.39 / 662.53 / 749.42$ \\
\hline 550 & $532.86 / 547.75 / 577.29$ & $560.10 / 583.03 / 611.53$ \\
\hline
\end{tabular}

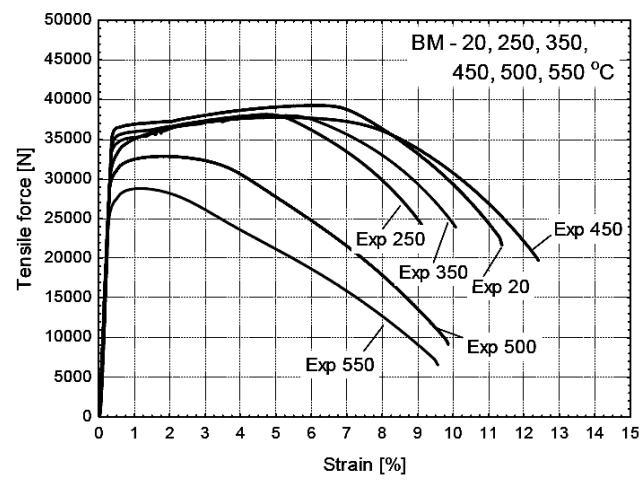

a

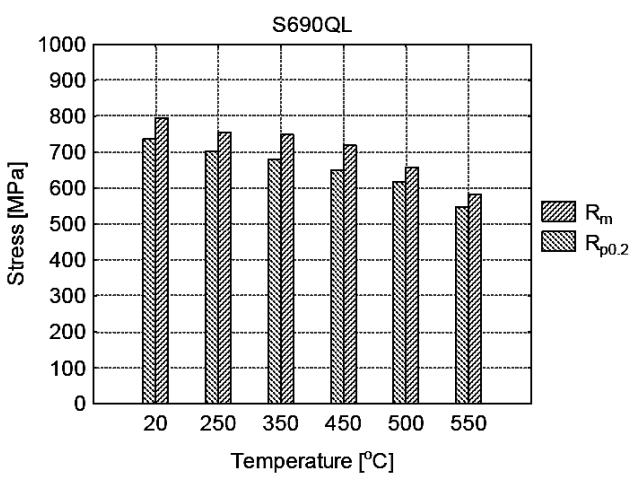

b

Fig. 1. Diagram of tensile testing (a) and histograms of the obtained properties $\left(R_{p 0.2}\right.$ and $\left.R_{m}\right)$ at elevated temperatures (b) [2].

Testing of the S690QL has shown that a significant decrease in mechanical properties occurs at the temperatures higher than $450^{\circ} \mathrm{C}$ (Fig. 2). With further increase in temperatures this decrease is more and more evident.

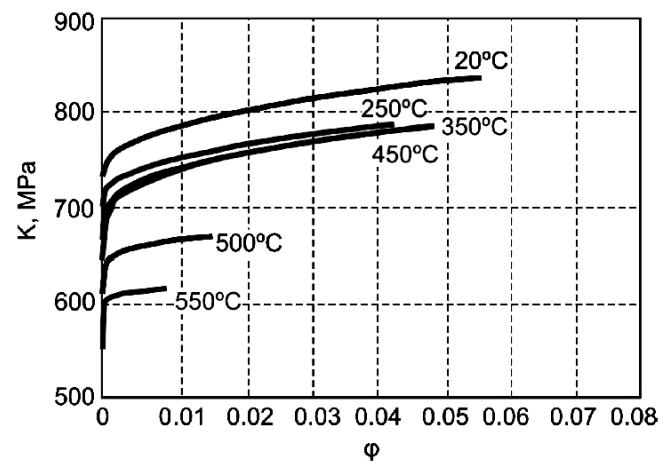

Fig. 2. Strengthening curves for each testing temperature.

\section{Numerical Analysis of Tensile Test.}

2.1. Strengthening Curves for S690QL Steel. Strengthening of steel occurs during the tensile loading within the plasticity domain. This is why it is necessary to know the properties of the material within the plasticity domain, so that its stress and strain behavior 
could be predicted. Due to big problems that arise during the experimental measurement of the main strains, a simpler form of the hardening curve is used as the functional dependence of the specific strain resistance and strain represented graphically. The material's strain hardening curves are the initial point for derivation of the numerical analysis by the finite element method. There are more types of approximations, while here are given:

$$
\begin{gathered}
K=C \varphi^{n}, \\
K=C_{1}+C_{2} \varphi^{m},
\end{gathered}
$$

where

$$
C=R_{m} \frac{e^{n}}{n^{n}}, \quad C_{1}=R_{p}, \quad C_{2}=\frac{R_{m} e^{n}-R_{p}}{n\left(\frac{R_{m} e^{n}}{R_{m} e^{n}-R_{p}} n\right)}, \quad m=\frac{R_{m} e^{n}}{R_{m} e^{n}-R_{p}} n,
$$

$C, C_{1}, C_{2}$, and $n$ are the material constants, while $\varphi=\ln \left(l / l_{0}\right)$ is the natural (logarithmic) strain.

Detail procedure for strengthening curves determination is given in [19].

For one specimen at every testing temperature, the strengthening curve was calculated and the obtained results are shown in Table 2 and Fig. 2. That data is then used as base for numerical analysis.

$\mathrm{T}$ a b 1 e 2

Strength Hardening Curves for Each S690QL Steel Specimen

\begin{tabular}{|c|c|c|c|c|c||}
\hline $\begin{array}{c}\text { Testing } \\
\text { temperature, } \\
{ }^{\circ} \mathrm{C}\end{array}$ & $\begin{array}{c}\text { Yield } \\
\text { strength } \\
R_{p 0.2}, \mathrm{MPa}\end{array}$ & $\begin{array}{c}\text { Tensile } \\
\text { strength } \\
R_{m}, \mathrm{MPa}\end{array}$ & $\begin{array}{c}\text { Elongation } \\
A, \mathrm{~mm}\end{array}$ & $\begin{array}{c}K=C \varphi^{n}, \\
\mathrm{MPa}\end{array}$ & $\begin{array}{c}K=C_{1}+C_{2} \varphi^{m}, \\
\mathrm{MPa}\end{array}$ \\
\hline 20 & 736.65 & 793.02 & 11.05 & $984.8 \varphi^{0.05572}$ & $736.65+383.04 \varphi^{0.4589}$ \\
\hline 250 & 702.20 & 754.72 & 8.80 & $902.48 \varphi^{0.04316}$ & $702.2+298.22 \varphi^{0.3964}$ \\
\hline 350 & 678.94 & 748.42 & 9.78 & $910.4 \varphi^{0.0487}$ & $678.94+315.36 \varphi^{0.3581}$ \\
\hline 450 & 650.22 & 749.42 & 12.17 & $907.1 \varphi^{0.0471}$ & $650.22+312 \varphi^{0.2735}$ \\
\hline 500 & 612.48 & 658.39 & 9.64 & $712.64 \varphi^{0.015283}$ & $612.48+120.11 \varphi^{0.18229}$ \\
\hline 550 & 547.75 & 611.53 & 9.35 & $644.86 \varphi^{0.009356}$ & $547.75+102.493 \varphi^{0.08306}$ \\
\hline
\end{tabular}

2.2. Numerical Analysis of Necking of a Circular Bar. The second part of the paper presents performed numerical analysis based on finite element method using PAK software [17]. The objective of numerical analysis is to determine the degree of correlation between results obtained experimentally and numerically. If the numerical simulation can reliably provide results that are similar to those obtained by experiment, then expensive and extensive experiments of this type can be avoided in further research.

2.2.1. Large Strain Elastic-Plastic Analysis. The stress integration algorithm of large strain deformations in isotropic plasticity based on the multiplicative decomposition of the deformation gradient, using the logarithmic strains, is given in detail: 
1. Determination of the relative and normalized relative deformation gradient

$$
{ }_{t}^{t+\Delta t} \mathbf{F}=\mathbf{1}+\frac{\partial^{\Delta t} \mathbf{u}}{\partial^{t} \mathbf{x}},
$$

where $\frac{\partial^{\Delta t} \mathbf{u}}{\partial^{t} \mathbf{x}}$ is the displacement gradient,

$$
{ }_{t}^{t+\Delta t} \overline{\mathbf{F}}=\left|{ }_{t}^{t+\Delta t} \mathbf{F}\right|^{-1 / 3}{ }_{t}+\Delta t \mathbf{F} .
$$

2. Elastic trial solution

$$
{ }^{t+\Delta t} \overline{\mathbf{b}}^{E^{*}}={ }^{t+\Delta t}{ }_{t} \overline{\mathbf{F}}^{t} \overline{\mathbf{b}}^{E t+\Delta t}{ }_{t}^{t} \overline{\mathbf{F}}^{T}
$$

normalized trial left Cauchy-Green elastic deformation tensor.

Trial elastic principal stretch $\lambda_{A}^{E^{*}}$ and principal directions $\mathbf{q}_{A}$ of ${ }^{t+\Delta t} \overline{\mathbf{b}}^{E^{*}}$ an be determined using the spectral theorem. In relation to the rotated principal directions, tensor ${ }^{t+\Delta t} \overline{\mathbf{b}}^{E^{*}}$ and trial elastic logarithmic strain tensor ${ }^{t+\Delta t} \overline{\mathbf{e}}^{E^{*}}$ can be written as

$$
{ }^{t+\Delta t} \overline{\mathbf{b}}^{E^{*}}=\sum_{A=1}^{3}\left(\bar{\lambda}_{A}^{E^{*}}\right)^{2} \mathbf{q}_{A} \otimes \mathbf{q}_{A}
$$

and

$$
{ }^{t+\Delta t} \overline{\mathbf{e}}^{E^{*}}=\sum_{A=1}^{3} \ln \left(\bar{\lambda}_{A}^{E^{*}}\right) \mathbf{q}_{A} \otimes \mathbf{q}_{A} .
$$

3. Determination of the trial deviatoric elastic stress tensor and trial equivalent elastic stress:

$$
{ }^{t+\Delta t} \mathbf{S}^{E^{*}}=G \operatorname{dev}{ }^{t+\Delta t} \overline{\mathbf{b}}^{E^{*}}
$$

where $G$ is shear modulus,

$$
{ }^{t+\Delta t} \sigma^{E^{*}}=\sqrt{\frac{3}{2}}\left\|^{t+\Delta t} \mathbf{S}^{E^{*}}\right\|
$$

4. Checking of yield condition

$$
{ }^{t+\Delta t} f_{y}^{E}={ }^{t+\Delta t} \sigma^{E^{*}}-{ }^{t} \sigma_{y} \leq 0-\text { elastic solution go to } 6,
$$

where ${ }^{t} \sigma_{y}$ is yield stress.

5. Calling the program for the integration of constitutive relations $[20,21]$ to determine ${ }^{t+\Delta t} \mathbf{S}$ (deviatoric stress tensor) and $\left|{ }_{0}^{\tau} \mathbf{F}_{P}\right|$ (determinant of plastic deformation gradient),

$$
{ }^{t+\Delta t} \sigma=\sqrt{\frac{3}{2}}\left\|^{t+\Delta t} \mathbf{S}\right\|-\text { equivalent stress. }
$$


Check if $\left|t+\Delta t f_{y}\right|=\left|t+\Delta t \sigma-{ }^{t} \sigma_{y}\right|>0-$ new iteration, go to 5 .

6. Deformation gradient

$$
{ }_{0}^{t+\Delta t} \mathbf{F}={ }^{t+\Delta t} \mathbf{J}^{T}\left({ }^{0} \mathbf{J}^{-1}\right)^{T},
$$

where ${ }^{t+\Delta t} \mathbf{J}$ and ${ }^{0} \mathbf{J}$ are the Jacobian matrices at time $t+\Delta t$ and $t=0$.

Determinant of elastic deformation gradient using multiplicative decomposition

$$
\left|{ }_{\tau}^{t+\Delta t} \mathbf{F}_{E}\right|=\frac{\left|{ }_{0}^{t+\Delta t} \mathbf{F}\right|}{\left|{ }_{0}^{\tau} \mathbf{F}_{P}\right|} .
$$

7. Final stress solution

$$
\begin{gathered}
\sigma_{m}=c_{m} e_{m}, \\
e_{m}=\frac{1}{3}\left(\left|{ }_{\tau}^{t+\Delta t} \mathbf{F}_{E}\right|-1\right),
\end{gathered}
$$

where $e_{m}$ is the mean strain,

$$
\begin{gathered}
c_{m}=\frac{E}{1-2 v}, \\
{ }^{t+\Delta t} \sigma={ }^{t+\Delta t} \mathbf{S}+\sigma_{m} \mathbf{1} .
\end{gathered}
$$

8. Correction of elastic configuration at the end of step

$$
{ }^{t+\Delta t} \overline{\mathbf{b}}^{E}=\frac{1}{G}^{t+\Delta t} \mathbf{S}+\bar{b}_{m}^{E} \mathbf{1}
$$

where $\bar{b}_{m}^{E}=\frac{1}{3} t+\Delta t \bar{b}_{i i}^{E^{*}}$.

2.2.2. Numerical Results. Specimen is modeled with 2400 3D solid elements with 20 nodes per element. Elastic-plastic material model with isotropic hardening was used. Hardening zone is described by the Ramberg-Osgood curve ${ }^{t} \sigma_{y}=\sigma_{y v}+C_{y}\left({ }^{t} \bar{e}^{P}\right)^{n}$, where $\sigma_{y v}$ is the initial yield stress, ${ }^{t} \bar{e}^{P}$ is the normalized effective plastic strain, $C_{y}$ and $n$ material constants. Hardening parameters defined by experimental results are shown in Table 3.

Numerically obtained results for stress and logarithmic strain are compared with experimental results. Figure 3 shows comparative diagrams of those results at temperature range $20-550^{\circ} \mathrm{C}$.

In order to define the deviation of the numerical results from experimental ones, the statistical parameters - factors were adopted, for strength and strain of material for each of the experimental temperatures. Those factors were calculated in such a way that they take into account the values of force and elongation at certain points on the curve - at the yield strength, maximal force and fracture. A dimensionless variable was obtained through the mutual comparison, which shows the degree of deviation of numerical results with respect to experimental ones. Obtained results are shown in Table 4. 
D. Arsić, M. Djordjević, J. Zivković, et al.

$\mathrm{T}$ a b 1 e 3

\section{Experimentally Obtained Hardening Parameters Used in Numerical Calculations}

\begin{tabular}{|c|c|c|c||}
\hline Temperature, ${ }^{\circ} \mathrm{C}$ & $\sigma_{y v}, \mathrm{MPa}$ & $C_{y}$ & $n$ \\
\hline 20 & 736.65 & 383.040 & 0.45890 \\
\hline 250 & 702.20 & 298.220 & 0.39640 \\
\hline 350 & 678.94 & 315.360 & 0.35810 \\
\hline 450 & 650.22 & 312.000 & 0.27350 \\
\hline 500 & 612.48 & 120.110 & 0.18229 \\
\hline 550 & 547.75 & 102.493 & 0.08306 \\
\hline
\end{tabular}


Fig. 3. Diagrams of experimental and numerical tensile testing at temperature range from 20 to $550^{\circ} \mathrm{C}$. 
$\mathrm{T}$ a b 1 e 4

\section{Deviation of Numerical from Experimental Results}

\begin{tabular}{|c|c|c|c|c|c|c||}
\hline \hline Temperature, ${ }^{\circ} \mathrm{C}$ & $R_{p}^{I}$ & $\varepsilon_{p}^{I}$ & $R_{m}^{I}$ & $\varepsilon_{m}^{I}$ & $R_{F}^{I}$ & $\varepsilon_{F}^{I}$ \\
\hline 20 & 1.06 & 1.00 & 1.01 & 0.83 & 0.87 & 0.97 \\
\hline 250 & 1.04 & 1.00 & 0.96 & 1.00 & 0.88 & 1.03 \\
\hline 350 & 1.04 & 0.98 & 0.96 & 0.90 & 0.77 & 1.02 \\
\hline 450 & 1.09 & 1.00 & 0.98 & 0.73 & 0.35 & 0.90 \\
\hline 500 & 1.08 & 1.00 & 1.00 & 0.86 & 0.89 & 0.73 \\
\hline 550 & 1.11 & 1.00 & 1.07 & 1.00 & 1.67 & 0.64 \\
\hline$R_{p}^{I}=\frac{F_{p}^{n}}{F_{p}^{e}}$ (at yield strength), $R_{m}^{I}=\frac{F_{m}^{n}}{F_{m}^{e}}$ (at maximal force), $R_{F}^{I}=\frac{F_{F}^{n}}{F_{F}^{e}}$ (at specimen fracture), \\
$\varepsilon_{p}^{I}=\frac{\varepsilon_{p}^{n}}{\varepsilon_{p}^{e}}$ (at yield strength), $\varepsilon_{m}^{I}=\frac{\varepsilon_{m}^{n}}{\varepsilon_{m}^{e}}$ (at maximal force), $\varepsilon_{F}^{I}=\frac{\varepsilon_{F}^{n}}{\varepsilon_{F}^{e}}$ (at specimen fracture). \\
\hline
\end{tabular}

Results obtained show that the greater deviations appear at temperatures higher than $450^{\circ} \mathrm{C}$, especially for values of strain. As the limiting values, considered as acceptable are the values of factors $R^{I}$ and $\varepsilon^{I}$ from 0.9 to 1.1 , since in that range the deviations can be compensated by adopting the adequate safety degree during the structure's design. Deviation of the numerical results is the largest on the portions of curves after reaching the maximal force; until then one can say that the obtained results are satisfactory. As the cause for those deviations one can consider restrictions of the model for the numerical analysis, since it did not take into account all the variables in the tension process, like influence of the creep process at the higher temperature. The reason for omitting those influential parameters is the model simplification that was done for the sake of reducing the calculation time. In addition, during the calculations of the structure, one mainly takes into account only values of stresses and strains up to reaching the maximal force, so the last portion of the curve is considered as less important.

In the end, in Figs. 4-6 are shown stress field and effective plastic strain immediately before fracture for three specimens tested at 20,250 , and $350^{\circ} \mathrm{C}$. To obtain strain in percents values from scales on the right should be multiplied by 100 . Some authors have shown that similar approach for determination of the critical stress level can be applied to real constructions such as bucket wheel excavators [22] and seamless pipes [23].

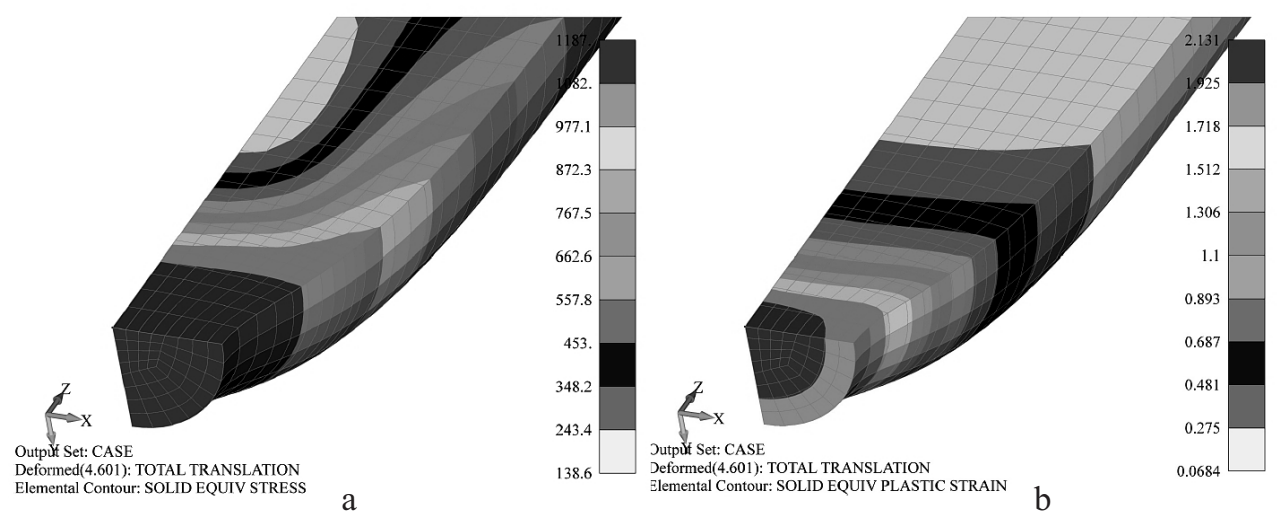

Fig. 4. Effective stress (a) and effective plastic strain (b) moment before fracture at $20^{\circ} \mathrm{C}$. 


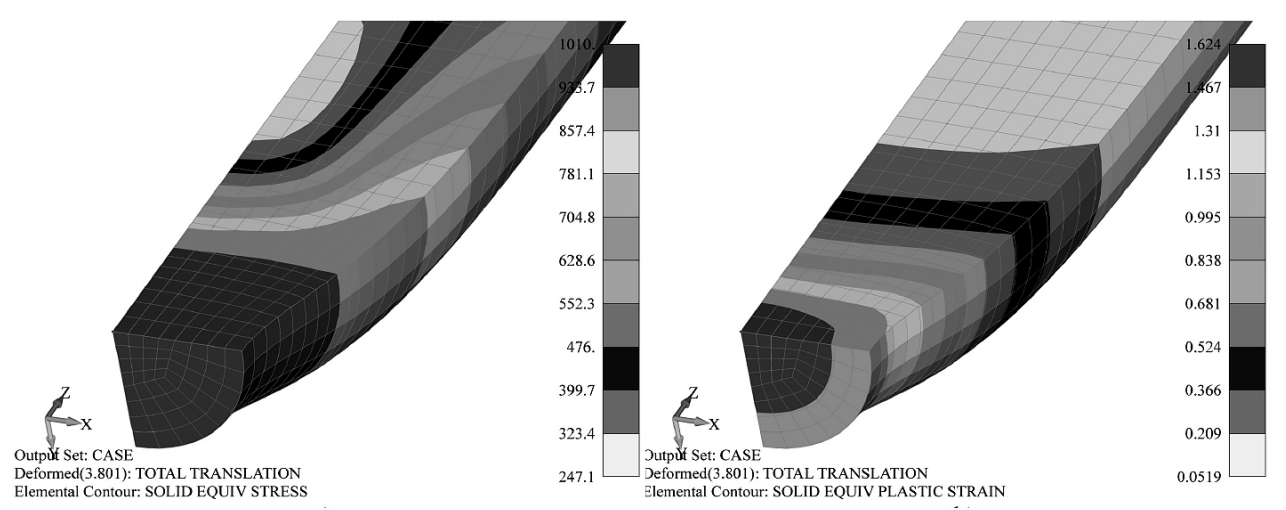

a

$\mathrm{b}$

Fig. 5. Effective stress (a) and effective plastic strain (b) moment before fracture at $250^{\circ} \mathrm{C}$.

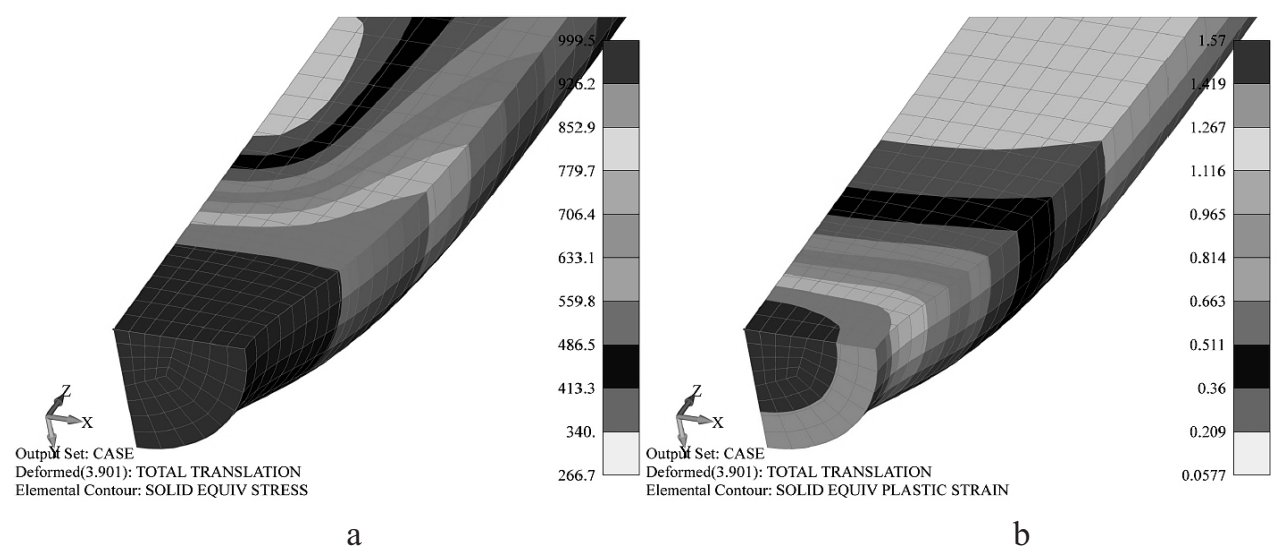

Fig. 6. Effective stress (a) and effective plastic strain (b) moment before fracture at $350^{\circ} \mathrm{C}$.

Conclusions. The results obtained in this paper show the influence of elevated temperatures on mechanical properties of the steel S690QL. The specimens were tested in the temperature range $20-550^{\circ} \mathrm{C}$.

The obtained experimental results have shown a significant decrease in the yield stress and tensile strength of the specimens at temperatures higher than $450^{\circ} \mathrm{C}$. Results of numerical analysis shown high correlation with the experimental results. It is confirmed the fact that the temperature of $450^{\circ} \mathrm{C}$ is the critical temperature when decreasing of mechanical properties occur. Therefore, simulation of tensile test at elevated temperatures can be performed with obtaining good and reliable results, thus avoiding conduction of expensive and long experiments. We hope that the results obtained will be useful to process engineers in constructing and operating stuctures of S690QL steel.

Acknowledgments. This research was financed by the Ministry of Education, Science and Technological development of Republic of Serbia through project TR35024. The authors are very grateful for this funding.

\section{Р е 3 ю м е}

Представлено результати розрахунково-експериментального аналізу впливу температури на механічні властивості високоміцної конструкційної сталі S690QL. Визна- 
чено максимальну температуру при статичних випробуваннях на розтяг, за якої ця сталь зберігає високі механічні характеристики. Статичні випробування на розтяг проводились за п’яти різних температур у діапазоні $20 \ldots 550^{\circ} \mathrm{C}$. Отримані експериментальні дані порівнювались з результатами скінченноелементних розрахунків шляхом побудови відповідних кривих зміцнення сталі.

1. D. Arsić, V. Lazić, R. Nikolić, et al., "Application of the S690QL class steels in responsible welded structures," Mater. Eng. - Mater. Inž., 20, No. 4, 174-183 (2013).

2. V. Lazić, S. Aleksandrović, D. Arsić, et al., "The influence of temperature on mechanical properties of the base material and welded joint made of steel S690QL," Metalurgija-Metallurgy, 55, No. 2, 213-216 (2016).

3. X. Qiang, F. Bijlaard, and H. Kolstein, "Post-fire mechanical properties of high strength structural steels S460 and S690," Eng. Struct., 35, 1-10 (2012).

4. J. Outinen and P. Makelainen, "Mechanical properties of structural steel at elevated temperatures and after cooling down," Fire Mater., 28, 237-251 (2004).

5. J. Chen, B. Young, and B. Uy, "Behavior of high strength structural steel at elevated temperatures," J. Struct. Eng., 132, 1948-1954 (2006).

6. X. Qiang, F. Bijlaard, and H. Kolstein, "Dependence of mechanical properties of high strength steel S690 on elevated temperatures," Constr. Build. Mater., 30, 73-79 (2012).

7. S. P. Chiew, M. S. Zhao, and C. K. Lee, "Mechanical properties of heat-treated high strength steel under fire/post-fire conditions," J. Constr. Steel Res., 98, 12-19 (2014).

8. Welding Handbook, SSAB Oxelosund AB, Sweden (2009).

9. C. Moura Branco, R. Ritchie, and V. Sklenicka (Eds.), Mechanical Behaviour of Materials at High Temperature, NATO Science Partnership Subseries: 3 (Book 15), Springer (1996).

10. L. Remy and J. Petit (Eds.), Temperature-Fatigue Interaction, Elsevier Science \& Technology, USA (2002).

11. K. H. Chang and C. H. Lee, "Characteristics of high temperature tensile properties and residual stresses in weldments of high strength steels," Mater. Trans., 47, No. 2, 348-354 (2006).

12. S. Bošnjak, M. Arsić, S. Savićević, et al., "Fracture analysis of the pulley of a bucket wheel boom hoist system," Eksploatacja i Niezawodnosc - Maintenance and Reliability, 18, No. 2, 155-163 (2016).

13. V. S. Dzyuba and D. O. Kubchak, "Procedure for prediction of strength in composite materials with consideration of damage," Strength Mater., 47, No. 2, 362-367 (2015).

14. F-J. Zuo, L. Yu, J. Mi, et al., "Reliability analysis of gear transmission with considering failure correlation,“ Eksploatacja i Niezawodnosc - Maintenance and Reliability, 17, No. 4, 617-623 (2015).

15. S. Samborski, J. Wieczorkiewicz, and R. Rusinek, "A numerical-experimental study on damaged beams dynamics," Eksploatacja i Niezawodnosc - Maintenance and Reliability, 17, No. 4, 624-631, (2015).

16. J.-B. Yan, J. Y. R. Liew, M.-H. Zhang, and J.-Y. Wang, "Mechanical properties of normal strength mild steel and high strength steel S690 in low temperature relevant to Arctic environment," Mater. Design, 61, 150-159 (2014).

17. M. Kojić, R. Slavković, M. Živković, and N. Grujović, PAK-S: Program for FE Structural Analysis, Faculty of Mechanical Engineering, University of Kragujevac, Kragujevac, Serbia (1999). 
18. ISO 6892-2:2011: Metallic Materials - Tensile Testing - Part 2: Method of Test at Elevated Temperatures.

19. K. Lange, Handbook of Metal Forming, Society of Manufacturing Engineers, Dearborn, USA (1985).

20. M. Kojić and K. J. Bathe, Inelastic Analysis of Solids and Structures, Springer, Berlin-Heidelberg (2005).

21. M. Živković, Nonlinear Analysis of Constructions [in Serbian], University of Kragujevac, Faculty of Mechanical Engineering, Kragujevac, Serbia (2006).

22. M. Savković, M. Gasić, M. Arsić, and R. Petrović, "Analysis of the axle fracture of the bucket wheel excavator," Eng. Fail. Anal., 18, No. 1, 433-441 (2011).

23. B. Medjo, M. Rakin, M. Arsić, et al., "Determination of the Load Carrying Capacity of Damaged Pipes Using Local Approach to Fracture," Mat. Trans., 53, No. 1, 185-190 (2012). 